\title{
ANALYSIS OF COMMERCIAL GRAPE RAISINS: PHENOLIC CONTENT, ANTIOXIDANT CAPACITY AND RADICAL SCAVENGER ACTIVITY
}

\section{ANÁLISE DE UVAS PASSAS COMERCIAIS: CONTEÚDO FENÓLICO, CAPACIDADE ANTIOXIDANTE E ACTIVIDADE SEQUESTRADORA DE RADICAIS LIVRES}

\author{
Susana Sério ${ }^{1}$, Maria D. Rivero-Pérez ${ }^{2}$, Ana Cristina Correia ${ }^{1}$, António Manuel Jordão ${ }^{1}$, \\ Maria L. González-San José \\ ${ }^{1}$ Polytechnic Institute of Viseu (Centre for the Study of Education, Technologies and Health), Agrarian Higher School, Estrada de Nelas, Quinta \\ da Alagoa, Ranhados, 3500-606 Viseu, Portugal. \\ ${ }^{2}$ University of Burgos, Department of Biotechnology and Food Science, Plaza Misael Bañuelos s/n 09001, Burgos, Spain. \\ * corresponding author: António Manuel Jordão, Polytechnic Institute of Viseu (Centre for the Study of Education, Technologies and Health), \\ Agrarian Higher School, Estrada de Nelas, Quinta da Alagoa, Ranhados, 3500-606 Viseu, Portugal email: antoniojordao@esav.ipv.pt
}

(Received 07.05.2013. Accepted 08.04.2014)

\section{SUMMARY}

Seven different commercial grape raisins from the Spanish market were evaluated for total phenolic composition, antioxidant potential and scavenger activity. Commercial red raisins (from the Cardinal grape variety) generally had the significantly highest content of total phenolic compounds (406.9 mg/100 g raisin) and antioxidant capacity (27.88 mM Fe(II) and $10.73 \mathrm{mM}$ trolox, respectively by applying FRAP and ABTS methods) while commercial white raisins had the lowest content for the parameters analyzed, especially for commercial Moscatel of Alexandria and Sultana raisins (ranging from 110.8 to $284.4 \mathrm{mg} / 100 \mathrm{~g}$ raisin for total phenolic compounds and ranging from 6.0 to $17.04 \mathrm{mM}$ Fe(II) and from 2.43 to $8.94 \mathrm{mM}$ trolox, respectively for antioxidant capacity by applying FRAP and ABTS methods). Finally, the Pearson test shows a very high correlation $(0.95$ and $0.97, \alpha<0.05)$ between total phenolic content and antioxidant capacity. Results prove that all commercial raisin samples studied constitute a natural source of polyphenols and antioxidants, especially raisin samples obtained from the red grape variety.

\section{RESUMO}

Efetuou-se o estudo de 7 amostras diferentes de uvas passa comerciais disponíveis no mercado espanhol, ao nível dos compostos fenólicos totais, do potencial antioxidante e ainda da atividade sequestradora de radicais livres. As uvas passa tintas (variedade Cardinal) apresentaram no geral valores significativamente mais elevados de compostos fenólicos totais (406.9 mg/100 g uva passa), capacidade antioxidante (27.88 mM Fe(II) e $10.73 \mathrm{mM}$ trolox, respetivamente pela aplicação das metodologias FRAP e ABTS) enquanto que as uvas passa brancas apresentaram valores mais baixos, em particular as amostras das variedades Moscatel de Alexandria e Sultanas (variando os valores entre 110.8 e $284.4 \mathrm{mg} / 100 \mathrm{~g}$ uva passa, para os compostos fenólicos totais, entre 6.0 e $17.04 \mathrm{mM} \mathrm{Fe}(\mathrm{II})$ e entre 2.43 e $8.94 \mathrm{mM}$ trolox, respetivamente para a capacidade antioxidante pela aplicação dos métodos FRAP e ABTS). Finalmente, através da aplicação do Teste de Pearson observou-se a existência de elevada correlação (0.95 e $0.97, \alpha<0.05$ ) entre os compostos fenólicos totais e a capacidade antioxidante. Os resultados obtidos, provam que as amostras comerciais de uvas passa estudadas constituem uma fonte natural de compostos fenólicos e de antioxidantes, em especial as uvas passa tintas obtidas a partir da variedade Cardinal.

Key words: antioxidant activity, grape raisins, phenolic compounds.

Palavras-chave: capacidade antioxidante, uvas passa, compostos fenólicos.

\section{INTRODUCTION}

Food preservation methods have been applied for many years. One example is fruit drying. Dried fruits represent a relatively concentrated form of fresh fruit whereby moisture removal confers increased shelf life. These fruits are commonly consumed in large quantities in different countries, and raisins are consumed very often, especially in Mediterranean countries. For fresh consumption as well as for use in baking and confectionery, raisins are produced by dehydrating grapes using the heat of the sun, natural air drying, or a mechanical process of oven drying, artificially dried (dipped), and sulfur dioxide-treated (golden) raisins (Mary and Michael, 2003; Fadhel et al., 2005).

The United States is the world's leading raisin producer, producing 317.51 tons in 2007/2008. However, there are other important producers, such as Turkey, China, Iran, Chile, South Africa, Greece, Australia, Uzbekistan and Tunisia (Chiou et al., 2007; Andrew et al., 2010; Gary and Arianna, 2010; Ghrairi et al., 2013).

During the drying process changes occur in the grape composition, particularly increased sugar concentration due to the grape dehydration (Franco et al., 2004). In addition, there is an increase in total energy, nutrient density, fibre content, and often a 
significant increase in antioxidant activity compared to fresh fruit as a consequence of this concentration. The elevated antioxidant activity and browning index were related to the increase in polyphenol concentration during drying, and potentially the generation of Maillard reaction products, such as hydroxymethylfurfural (Sanz et al., 2001; Çağlarirmak, 2006), favoured by the high sugar concentration and the temperatures reached during the drying process which can enhance antioxidant activity (Yilmaz and Toledo, 2005; Moreno et al., 2007). However, the drying process can also lead to losses in total polyphenolic compounds and changes in free to total polyphenol ratios, as shown by Vinson et al. (2005) in six types of dried fruit.

The health benefits associated with fresh grape consumption are broadly known and linked to the richness of phenolic compounds such as gallic acid, catechin, anthocyanins and resveratrol, and a wide variety of procyanidins. These compounds have been demonstrated to have a wide range of biochemical and pharmacological effects, including anticarcinogenic, and antiatherogenic, antiinflammatory, antimicrobial, and antioxidant activities (Simonetti et al., 1997; Dell'Agli et al., 2004; Darra et al., 2012).

In recent years several authors have reported the phenolic composition and antioxidant capacity of different varieties of raisins, namely from Tunisia (Ghrairi et al., 2013), China (Meng et al., 2011), the United States (Parker et al., 2007; Zhao and Hall, 2008) and Australia (Bennett et al., 2011). However, the effects of industrial drying practices on polyphenolic content, antioxidant capacity and radical scavenger activities have not been systematically studied, especially in commercial raisin samples from the Iberian Peninsula. For this reason, the purpose of this study was to determine, total phenolic content, antioxidant capacity and scavenger activity and the relationship between them from a selection of commercial raisins produced from different grape varieties.

\section{MATERIAL AND METHODS}

\section{Raisin samples}

A total of 7 commercial raisin samples (from Vitis vinifera L. species) purchased at a local Burgos city market (Spain) were studied. One commercial raisin sample from the red grape variety (Cardinal) and three different commercial white raisin samples from Moscatel of Alexandria, Moscatel of Málaga and Sultana grape varieties were analyzed. For the Sultana grape variety four different commercial samples were analyzed. Visual appearance of the commercial raisin samples studied is shown in Figure 1.

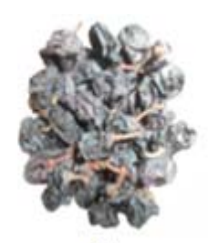

C

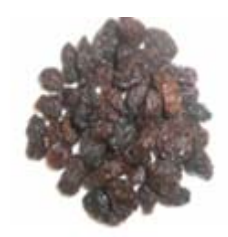

MO

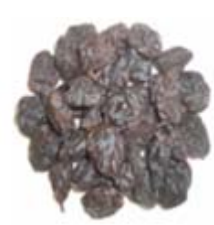

MA

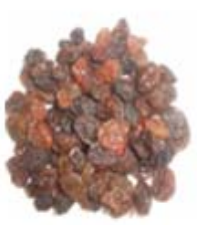

S I

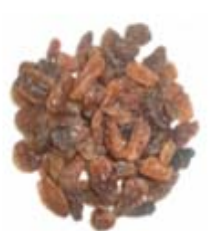

S II

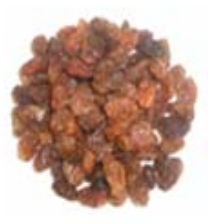

S III

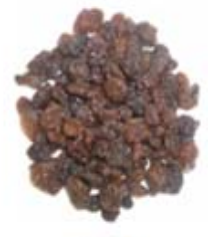

S IV

Figure 1 - Visual appearance of the commercial raisin samples studied. C - Cardinal; MO - Moscatel of Alexandria; MA - Moscatel of Málaga; SI, SII, SIII and SIV - Sultanas.

Aspeto visual das amostras de uvas passa estudadas. C - Cardinal; MO - Moscatel de Alexandria; MA - Moscatel de Málaga; SI, SII, SIII e SIV - Sultanas.

\section{Sample preparation}

The sample preparation method was based on what was described by Izcara and González-San José (2001), consisting of extracting phenolic compounds from raisins by a methanol:formic acid (97:3, v/v) solution as an extracting solvent. A first extraction was carried out adding $25 \mathrm{~mL}$ of extracting solvent to each set of $20 \mathrm{~g}$ of ground raisins. This first extraction was performed while stirring for 24 hours at room temperature and protected from light. After the first extraction, the supernatant was collected and a second extraction was carried out for 6 hours under the same conditions. In the end the two supernatants were collected. The process was carried out in triplicate for each commercial type of raisins under analysis.

\section{Total phenolic content}

The total phenolic content of the raisin samples was determined with a Folin Ciocalteu reagent, using gallic acid as the standard. The Singleton and Rossi (1965) improved method was applied. The results 
were expressed as gallic acid equivalents (mg/100 g raisin).

\section{Antioxidant capacity}

ABTS method: This assay is based on discolouration which occurs when the radical cation $\mathrm{ABTS}^{+}$is reduced to ABTS (2,2'-azinobis-3ethylbenzothiazoline-6-sulfonic acid) ( $\mathrm{Re}$ et al., 1999). The radical was generated by the reaction of a $7 \mathrm{mM}$ solution of ABTS in water with $2.45 \mathrm{mM}$ potassium persulphate $(1: 1)$. The radical solution shows stable absorbance values up to $16 \mathrm{~h}$ from the time of mixture. This reaction time takes place in darkness at room temperature. According to previous papers (Rivero-Pérez et al., 2007), the assay was made up with $980 \mu \mathrm{L}$ of $\mathrm{ABTS}^{+}$solutions and $20 \mu \mathrm{L}$ of the raisin extract sample (at a dilution of 1:50 in water). Absorbance measurements at $734 \mathrm{~nm}$ were made after $15 \mathrm{~min}$ of reaction time.

FRAP method: This method was used to measure the reductive power of a sample (Benzie and Strain, 1996). It is based on increased absorbance at $593 \mathrm{~nm}$ due to the formation of tripyridyl-s-triazine complexes with iron(II) (TPTZFe(II)) in the presence of a reductive agent. The reactive mixture was prepared by mixing a $25 \mathrm{~mL}$ sodium acetate buffer solution (0.3 mol/L, pH 3.6), $2.5 \mathrm{~mL}$ TPTZ (10 $\mathrm{mmol} / \mathrm{L}), 2.5 \mathrm{~mL} \mathrm{FeCl}_{3}(20 \mathrm{mmol} / \mathrm{L})$ and $3 \mathrm{~mL}$ water. $30 \mu \mathrm{L}$ of diluted raisin extract sample (diluted in water at $1: 10$ ) was added to $970 \mu \mathrm{L}$ of the latter reactive mixture and incubated at $37^{\circ} \mathrm{C}$ for $30 \mathrm{~min}$. The results were expressed as $\mathrm{mM} \mathrm{FeII}$, using linear calibration obtained with different concentrations of $\mathrm{FeSO}_{4}$.

\section{Radical scavenger activity}

Radical scavenger activities toward hydroxyl radical (HRSA) and superoxide radical (SRSA) were measured, because they are two of the most biologically active reactive oxygen species.

Hydroxyl radical-scavenging activity (HRSA): Deoxyribose (2-deoxy-D-ribose) decays when exposed to hydroxyl radicals generated by the Fenton reaction (Halliwell et al., 1987). The hydroxyl radicals $(\mathrm{HO} \bullet)$ were generated through the following system: $10 \mu \mathrm{L}$ of $\mathrm{FeCl}_{3}(0.1 \mathrm{mmol} / \mathrm{L}), 10 \mu \mathrm{L}$ of ascorbic acid $(0.1 \mathrm{mmol} / \mathrm{L}), 10 \mu \mathrm{L}$ of $\mathrm{H}_{2} \mathrm{O}_{2}$ (1 $\mathrm{mmol} / \mathrm{L})$, and $10 \mu \mathrm{L}$ of EDTA $(0.1 \mathrm{mmol} / \mathrm{L})$. Raisin extract samples $(15 \mu \mathrm{L}$ at a dilution of $1: 50$ in distilled water) were incubated at $37^{\circ} \mathrm{C}$ for $1 \mathrm{~h}$, with $20 \mu \mathrm{L}$ of desoxyribose ( $1 \mathrm{mmol} / \mathrm{L}$ final concentration) in the presence of $\mathrm{FeCl}_{3}$, ascorbic acid, $\mathrm{H}_{2} \mathrm{O}_{2}$, and EDTA. $1.5 \mathrm{~mL}$ of trichloroacetic acid $(28 \%, \mathrm{w} / \mathrm{v})$ and $1 \mathrm{~mL}$ of thiobarbituric acid $(1 \%$, w/v, $0.05 \mathrm{~mol} / \mathrm{L}$ $\mathrm{NaOH})$ were added to $1 \mathrm{~mL}$ of the raisin extract sample under incubation and held for $15 \mathrm{~min}$ at 100 ${ }^{\circ} \mathrm{C}$, after which it was left to cool down to room temperature. The malondialdehyde formed from the decay of desoxyribose was evaluated by reaction with thiobarbituric acid and measured at $532 \mathrm{~nm}$. The final results were expressed as inhibition percent in relation to a control test (without the sample).

Superoxide radical-scavenging activity (SRSA): The superoxide radical reacts with 4-nitroblue tetrazolium chloride to generate a coloured compound with absorbance to $560 \mathrm{~nm}$ (Liu et al., 1997). The antioxidant scavenging superoxide radical values are associated with the colouration formed during the reaction process. The reactive solution was made with $50 \mu \mathrm{L}$ of nicotinamide $(77 \mu \mathrm{mol} / \mathrm{L}), 50 \mu \mathrm{L}$ of $4-$ nitroblue tetrazolium chloride $(50 \mu \mathrm{mol} / \mathrm{L})$, and $5 \mu \mathrm{L}$ of phenazin methosulfate $(3.3 \mu \mathrm{mol} / \mathrm{L}$ final concentration) in a medium of $16 \mathrm{mmol} / \mathrm{L}$ Tris $-\mathrm{HCl}$, $\mathrm{pH} 8$, and $10 \mu \mathrm{L}$ of the raisin extract sample. The results were expressed as a percentage of inhibition in relation to a control test (without the sample).

\section{Statistical analysis}

All data are expressed as the mean \pm standard deviation from three replicates (i.e., data from three different extracts obtained from a given sample of commercial raisins). In order to determine whether there was a statistically significant difference between the results obtained for the different analytical parameters studied from the commercial raisin samples analysed, an analysis of variance and comparison of treatment means (ANOVA, one-way) were carried out with SPSS software (version 20.0). Differences between means were tested using Scheffler's test $(\alpha<0.05)$. In addition, Pearson coefficients of correlation values were also determined using the same statistical software.

\section{RESULTS AND DISCUSSION}

\section{Total phenolic content}

The data reported in Figure 2 show total phenolic compounds of the different commercial raisins analysed. The results show that the levels of total phenolic compounds in the commercial raisin samples differed significantly $(\alpha<0.05)$ between all samples produced from the different grape varieties (Cardinal, Moscatel of Alexandria, Moscatel of Málaga and Sultana). However, for the commercial raisins produced from the Sultana variety, no significant difference was found among three of the samples analysed (SII, SIII and SIV). Thus, total phenolic compound values ranged from 110.8 to $406.9 \mathrm{mg} / 100$ $\mathrm{g}$ raisin (average value of $215.8 \mathrm{mg} / 100 \mathrm{~g}$ raisin) for all raisin grapes analysed. As expected, commercial white raisin samples having the lowest phenolic concentration (ranging from 110.8 to $284.1 \mathrm{mg} / 100 \mathrm{~g}$ raisin) while commercial red raisin grapes (Cardinal variety) had the highest phenolic concentration (406.9 $\mathrm{mg} / 100 \mathrm{~g}$ raisin) which may be related to the presence of several phenolic compounds in high quantity, such as procyanidins in their skins. According to Williamson and Carughi (2010), the most abundant phenolic compounds in raisins are usually quercetin and kaempferol, and phenolic acids, as well as 
caftaric and coumaric acids. Compared to the total phenolic concentrations reported for other raisins, values found in the commercial raisin samples tested were comparable to concentrations found by other authors in other raisin varieties (Pastrana-Bonilla et al., 2003; Chiou et al., 2007). However, the values obtained in this study were lower than the values quantified by Meng et al. (2011) in several raisins produced in a Chinese province.

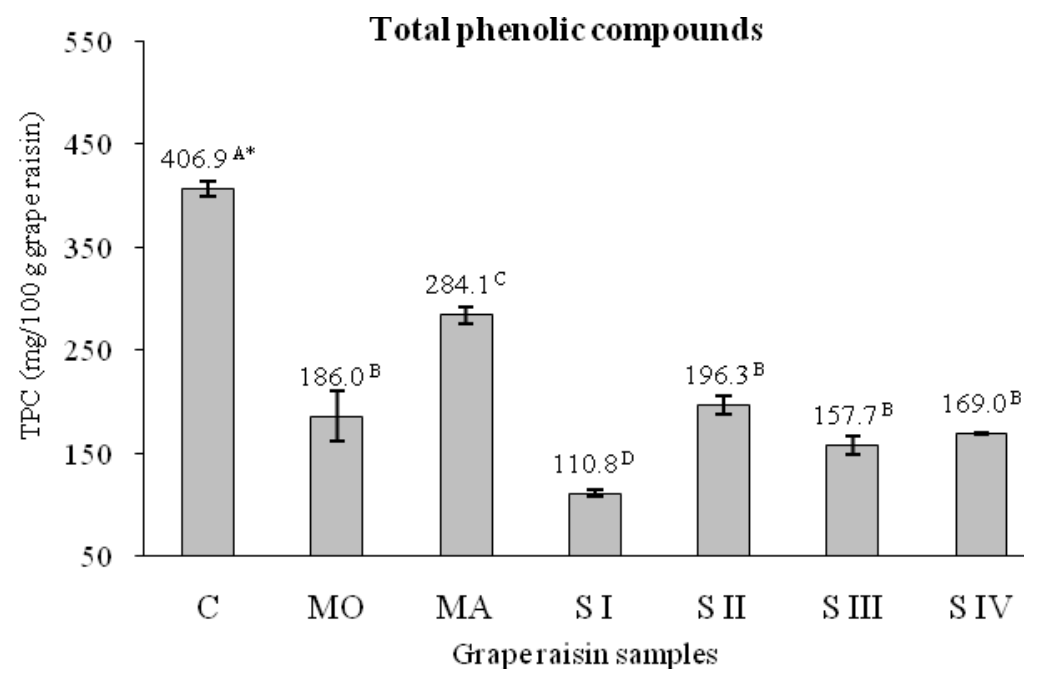

Figure 2 - Total phenolic compounds of the commercial raisin samples studied. C - Cardinal; MO - Moscatel of Alexandria; MA - Moscatel of Málaga; SI, SII, SIII and SIV - Sultanas. Different letters indicate statistically significant differences between the different samples tested according to the Scheffler's test $(\alpha<0.05)$. Result expressed in fresh weight.

Compostos fenólicos totais das amostras comerciais de uvas passa estudadas. C - Cardinal; MO - Moscatel de Alexandria; MA - Moscatel de Málaga; SI, SII, SIII e SIV - Sultanas. Letras diferentes indicam valores estatisticamente diferentes entre as diferentes amostras estudadas de acordo com o teste de Scheffler $(\alpha<0.05)$. Resultado expresso em peso fresco.

Most of the phenolic compounds during drying process as a result of the concentration effect resulting from the loss of water in grapes. However, processing grapes into raisins may also result in the loss of phenolic compounds resulting from enzymatic and air oxidation which occurs during the drying process (Breksa et al., 2010; Bennett et al., 2011). According to Figueiredo-González et al. (2013), some phenolic fractions such as hydroxycinnamic acids, anthocyanins and flavan-3-ol derivatives are involved in oxidative reactions by enzymatic pathways, which contribute to degrading them and to the browning of grapes. Karadeniz et al. (2000) studied raisin samples, including sun-dried, dipped, and golden raisins, and found that flavonols were not influenced by processing while procyanidins and flavan-3-ols were completely degraded in all raisin samples. This problem could be partially circumvented by if producers utilize varieties with increased phenolic concentrations to produce raisins, because we know that genetic factors (other than skin colour) are key influencers of a grape cultivar's phenolic content (Jordão et al., 2001; Gatto et al., 2008; Costa et al., 2014).

\section{Antioxidant capacity and scavenger activity}

For a more comprehensive and accurate evaluation of the antioxidant capacity and scavenger activity of commercial raisins samples, four antioxidant activity assays (ABTS, FRAP, SRSA and HRSA) were selected for their different functions. The antioxidant capacity and scavenger activity of all commercial raisin samples are shown in Figures 3 and 4.

Generally, it was clear that the antioxidant capacity results of the 7 commercial raisin samples analysed show a dispersion of the values between all of the samples tested (Figure 3). This result was independent of the two antioxidant methods used. Thus, antioxidant capacity values ranged from 6.0 to $27.88 \mathrm{mM}$ Fe(II) for the FRAP method and from 2.43 to $10.73 \mathrm{mM}$ trolox for the ABTS method. Of the 7 commercial grape raisin samples, red grape raisin samples produced from the Cardinal variety had a significantly $(\alpha<0.05)$ higher antioxidant capacity (27.88 $\mathrm{mM} \mathrm{Fe}$ (II) and $10.73 \mathrm{mM}$ trolox, for the FRAP and ABTS methods, respectively). In contrast to their antioxidant capacity, white commercial raisin samples had the lowest antioxidant capacity, especially the commercial raisin samples of the Sultana variety (ranging from 6.0 to $9.56 \mathrm{mM}$ and from 2.43 to 4.57 $\mathrm{mM}$ for the FRAP and ABTS methods, respectively). The commercial raisin sample produced from the Moscatel of Alexandria grapes also had a low level of antioxidant capacity. It is important to note, that, as for total phenol content, it was also observed that the commercial raisin samples obtained from red and/or seed-containing berries (Cardinal and Malaga Muscatel varieties) showed a higher antioxidant capacity than the samples produced from the seedless grape variety (Sultana variety). Recently, Costa et al. 

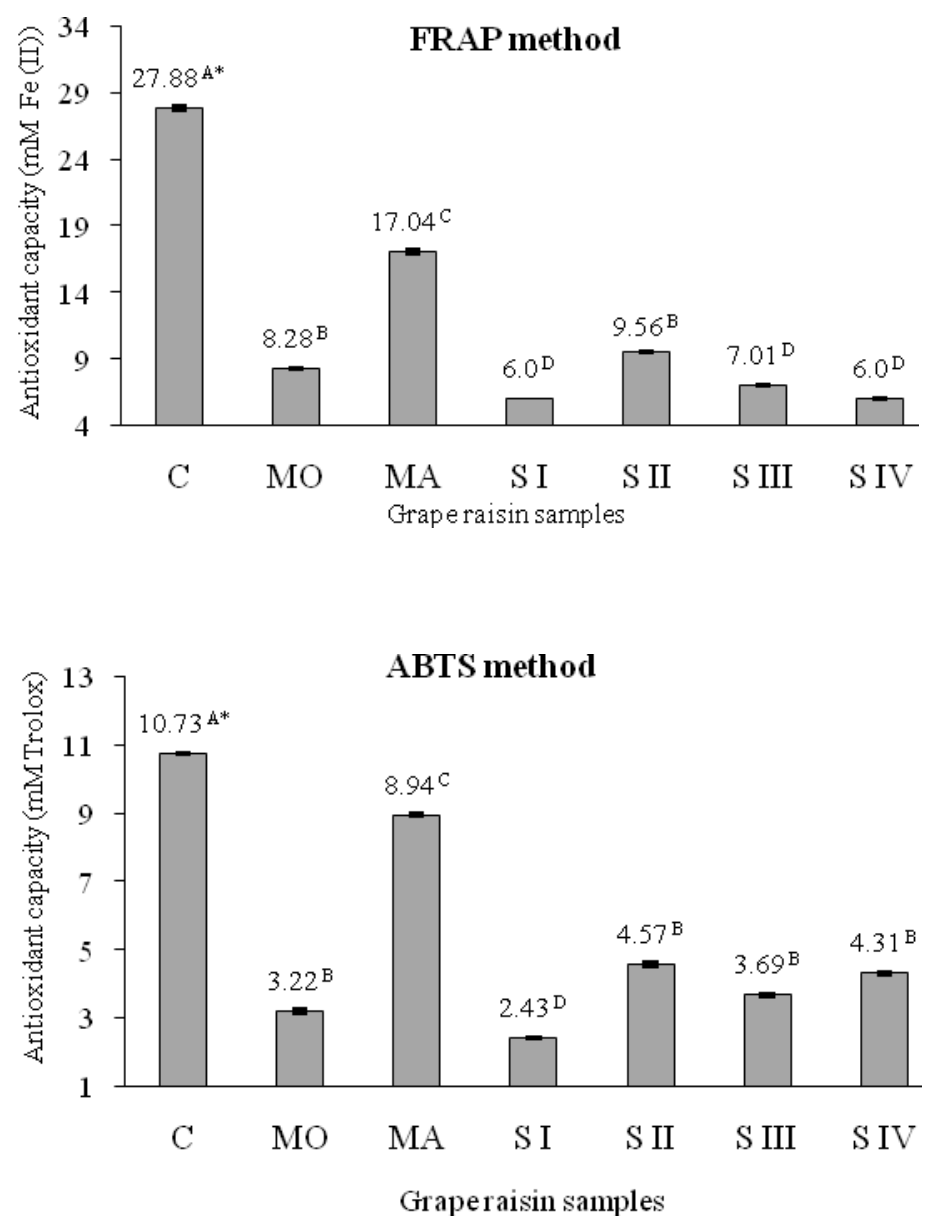

Figure 3 - Antioxidant capacity (FRAP and ABTS methods) of the commercial raisin samples studied. C - Cardinal; MO - Moscatel of Alexandria; MA - Moscatel of Málaga; SI, SII, SIII and SIV - Sultanas. Different letters indicate statistically significant differences between the different samples tested according to the Scheffler's test $(\alpha<0.05)$.

Capacidade antioxidante (métodos FRAP e ABTS) das amostras comerciais de uvas passa estudadas. C - Cardinal; MO - Moscatel de Alexandria; MA - Moscatel de Málaga; SI, SII, SIII e SIV - Sultanas. Letras diferentes indicam valores estatisticamente diferentes entre as diferentes amostras estudadas de acordo com o teste de Scheffler $(\alpha<0.05)$.

(2014) analysed 24 different grape varieties cultivated in two Portuguese wine regions and concluded that seeds were the grape berry fraction with the highest antioxidant capacity followed by the skins and pulp, irrespective the grape variety studied. In addition, there are other factors that could affect the polyphenolic and antioxidant capacity of this type of natural products such as the specific effects of drying (Bennett et al., 2011) and storage conditions (Sanz et al., 2001). On the other hand, the antioxidant capacity of a certain material such as grapes is nearly always associated with the quality and quantity of phenolics in the samples (Rodríguez-Bernaldo de Quirós et al., 2009; Costa et al., 2014). In addition, for Jayaprakasha et al. (2001), the antioxidant capacity of raisins is associated, not only with experimental materials, but also with extraction solvents, extract concentration, and the reaction time of the methodologies used.

The data in Figure 4 show the scavenger activity results quantified in the commercial raisin samples tested. As shown in Figure 4, through the SRSA method, the results obtained ranged from 14.94 to $36.47 \%$ (average value of $23 \%$ ), while as a result of using the HRSA method, the values ranged from 33.75 to $53.59 \%$ (average value of $44 \%$ ). For the HRSA method, these results are slightly lower than those obtained by Meng et al. (2011) in 9 different raisin varieties from China and that ranged from 53.07 to $81.16 \%$. In addition, according to Sun et al. (2010) polysaccharide compounds that are abundantly found in raisins also contribute to the scavenger activity of raisins.

As for the individual scavenger activity of the different commercial raisin samples tested, superoxide radical scavenger activity (SRSA) data revealed that the scavenger activity tendencies were similar to those obtained for total phenolic compounds and antioxidant capacity values. Thus, the Cardinal variety commercial red grape raisin sample had a significantly higher scavenger activity value (36.47\%) than commercial white grape raisin samples 

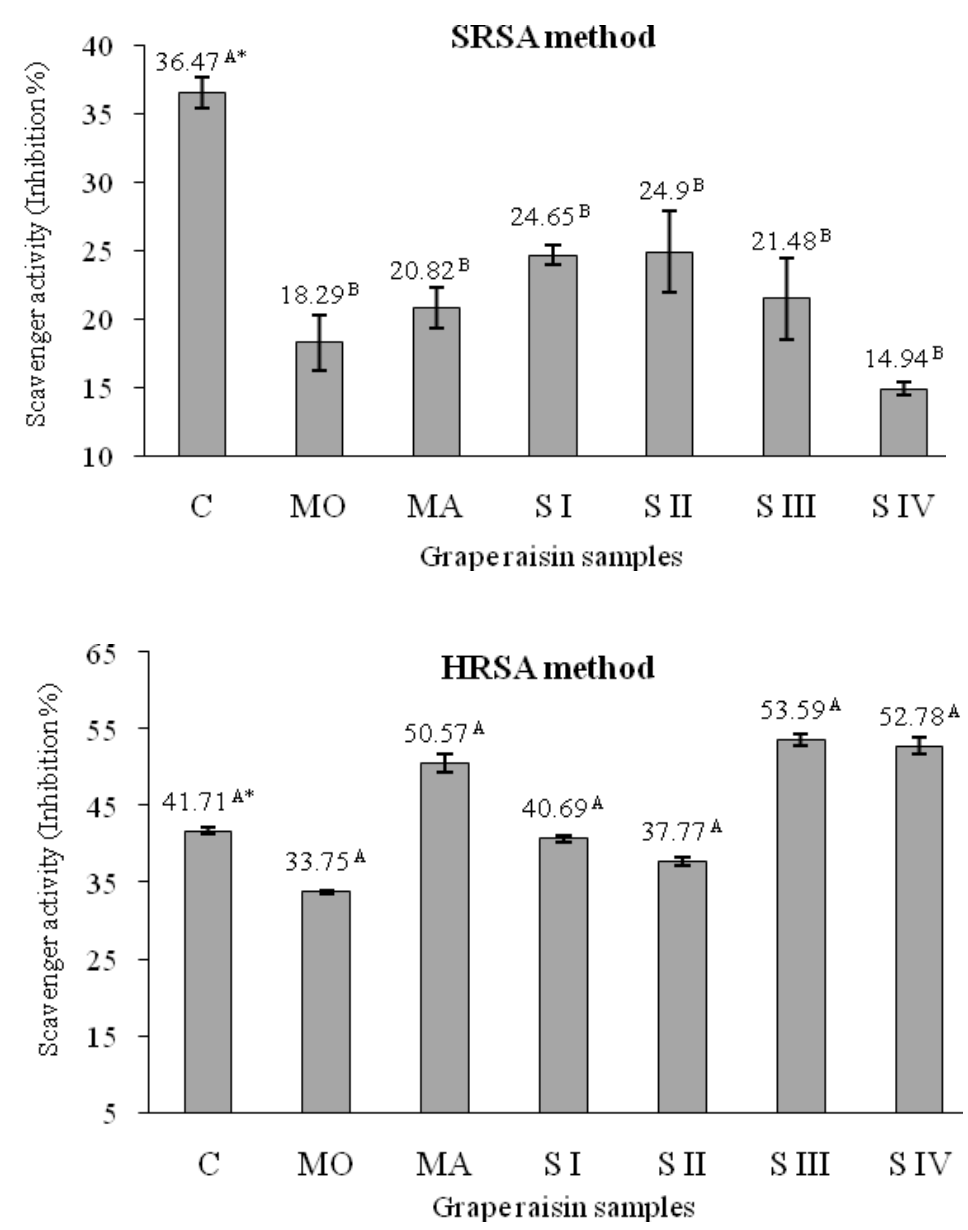

Figure 4 - Scavenger activity (SRSA and HRSA methods) of the commercial raisin samples studied. C - Cardinal; MO - Moscatel of Alexandria; MA - Moscatel of Málaga; SI, SII, SIII and SIV - Sultanas. * Different letters indicate statistically significant differences between the different samples tested according to the Scheffler's test $(p<0.05)$.

Atividade sequestradora de radicais livres (métodos SRSA e HRSA) das amostras comerciais de uvas passa estudadas. C - Cardinal; MO Moscatel de Alexandria; MA - Moscatel de Málaga; SI, SII, SIII e SIV - Sultanas. * Letras diferentes indicam valores estatisticamente diferentes entre as diferentes amostras estudadas de acordo com o teste de Scheffler $(p<0.05)$.

from other grape varieties (Moscatel of Alexandria, Moscatel of Malaga and Sultana). However, for radical scavenger activities through the hydroxyl radical (HRSA), no significant differences were detected between the scavenger activities of the different commercial raisin samples tested. From these results it becomes clear that the scavenger activity values depend on the method used. This divergence is probably due to the different reactivates of the polyphenols with each method applied. Thus, one single method cannot comprehensively demonstrate the scavenger activity of substances. First, organisms have more than one antioxidant system and second, different free radicals have different antioxidant clearance mechanisms (Meng et al., 2011). Finally it is important to note, that the potential differences in drying and storage conditions that induce, for example, a potential polyphenolic and enzymatic composition could also determine different raisin compositions and consequently generate different radical scavenger activities toward hydroxyl radicals. For Noda et al. (1997) the solubilisation of the components of natural extracts is another factor that must be taken into consideration when evaluating the results of hydroxyl and superoxide radical scavenging activities of natural products. In addition, the use of treatments such as heat, filtration, and enzymatic treatments will help clarify the relative contribution of components to radical scavenging activity.

\section{Correlation between the different variables}

Table I shows the Pearson correlation coefficients between total phenolic content, different antioxidant capacity methods, and different radical scavenger methodologies. The Pearson test shows a very high correlation $(0.97$ and $0.95, \alpha<0.05)$ between total phenolic content and antioxidant capacity (measured by the ABTS and FRAP methods). These high correlation results between total phenolic content and antioxidant capacity quantified by two methodologies are in accordance with those reported by other authors 
in raisins obtained from different grape varieties (Borbolan et al., 2003; Orak, 2007; Breksa et al., 2010). In addition, it is important to note that when we used the Folin-Ciocalteu reagent for total phenol determination (such as was used in this study), we not only measure polyphenols but also the total reducing substances from the sample. A high correlation value (0.94, $\alpha<0.05)$ was also obtained between the two antioxidant capacity methodologies (ABTS and FRAP). The SRSA method exhibited a weaker correlation with total phenol content $(0.47, \alpha<0.05)$ and with the other antioxidant methodologies (0.56 and $0.47, \alpha<0.05$, for FRAP and ABTS, respectively). Finally, as for the HRSA method, the results showed that this method did not have any correlation with total phenolic content and the different antioxidant methodologies. This result is similar to what was obtained by Meng et al. (2011), who reported a negative correlation between HRSA and other phenolic parameters, such as total polyphenol and total flavanoid compounds. The low correlation or uncorrelated values (especially for HRSA) probably imply that, generally, the raisin extracts with the greatest ability to transfer hydrogen atoms are the least effective at stabilizing the hydroxyl radical.

TABLE I

Pearson coefficients of correlation values $(\alpha<0.05)$ calculated for commercial raisin samples studied.

Valores do coeficiente de correlação de Pearson $(\alpha<0.05)$ calculados para as amostras comerciais de uvas passa estudadas

\begin{tabular}{|c|c|c|c|c|c|}
\hline \multirow[b]{2}{*}{ Variables } & \multicolumn{5}{|c|}{ Commercial raisin samples $(n=21)$} \\
\hline & $\mathrm{TPC}$ & FRAP & ABTS & SRSA & HRSA \\
\hline $\mathrm{TPC}$ & --- & 0.97 & 0.95 & 0.47 & n.c. \\
\hline FRAP & --- & --- & 0.94 & 0.56 & n.c. \\
\hline ABTS & --- & --- & --- & 0.47 & n.c. \\
\hline SRSA & --- & --- & --- & --- & n.c. \\
\hline HRSA & --- & --- & --- & --- & --- \\
\hline
\end{tabular}

$\mathrm{TPC}=$ total phenolic compounds; FRAP and ABTS = antioxidant capacity methods; SRSA and HRSA = scavenger activity methods; n.c. $=$ not correlated.

$\mathrm{TPC}=$ compostos fenólicos totais; FRAP e ABTS = métodos de capacidade antioxidante; SRSA e HRSA = métodos de atividade sequestradora de radicais livres; n.c. $=$ não correlacionados.

Thus, it was clear that HRSA and SRSA showed different correlations, which is in line with the results obtained by Rivero-Pérez et al. (2007) when these authors studied the profiles of the antioxidant capacity and radical scavenger activity of red wines through various methods. In addition, these results confirm the hypothesis that different mechanisms are involved in capturing both types of radicals or their related compounds. These factors may contribute to the differences in correlation coefficients between the different methodologies and between the different studies carried out on this subject matter.

\section{CONCLUSIONS}

Raisins from 7 different commercial samples were studied for their antioxidant capacity, scavenger activity and total phenolic content in this study. The red, Cardinal variety raisin sample had the significantly highest total phenolic compound content (average value of $406.9 \mathrm{mg} / 100 \mathrm{~g}$ raisin) and antioxidant capacity (average value of $27.88 \mathrm{mM}$ $\mathrm{Fe}(\mathrm{II})$ and $10.73 \mathrm{mM}$ trolox, respectively by applying the FRAP and ABTS methods). In contrast, commercial white raisin samples showed the significantly lowest total phenolic compound content (average value of $719.9 \mathrm{mg} / 100 \mathrm{~g}$ raisin) and antioxidant capacity (average value of 8.98 and 4.52 $\mathrm{mM}$ trolox, respectively by applying the FRAP and ABTS methods). In addition, high correlation coefficient values between total phenolic content, antioxidant capacity and among the different methods for quantifying antioxidant capacity were obtained.

Thus, the results obtained confirm that commercial raisins constitute a natural source of polyphenols and antioxidants. However, the comparison of these values should be conducted with caution since they are obtained from a limited number of commercial raisin samples and the results could vary notably with respect to others.

\section{REFERENCES}

Andrew P., Gary R., Marlene B., Ana V., Justine V., 2010. Antioxidant activity and phenolic content of 16 raisin grape (Vitis vinifera L.) cultivars and selections. Food Chem., 121, 740-745.

Bennett L.E., Jegasothy H., Konczak I., Frank D., Sudharmarajan S., Clingeleffer P.R., 2011. Total polyphenolics and anti-oxidant 
properties of selected dried fruits and relationships to drying conditions. J. Funct. Foods, 3, 115-124.

Benzie I.F.F., Strain J.J., 1996. The ferric reducing ability of plasma (FRAP) as a measure of 'antioxidant power': the FRAP assay. Anal. Biochem., 239, 70-76.

Borbolan A.M.A., Zorro L., Guillen D.A., Barroso C.G., 2003. Study of the polyphenol content of red and white grape varieties by liquid chromatography-mass spectrometry and its relationship to antioxidant power. J. Chromatogr. A, 1012, 31-38.

Breksa A.P., Takeoka G.R., Hidalgo M.B., Vilches A., Vasse J., Ramming D.W., 2010. Antioxidant activity and phenolic content of 16 raisin grape (Vitis vinifera L.) cultivars and selections. Food Chem., 121, 740-745.

Cağlarirmak N., 2006. Ochratoxin A, hydroxymethylfurfural and vitamin C levels of sun-dried grapes and sultanas. J. Food Process. Preserv., 30, 549-562.

Chiou A., Karathanos V., Mylona A., Salta F., 2007. Currants (Vitis vinifera L.) content of simple phenolics and antioxidant activity. Food Chem., 102, 516-522.

Costa E., Cosme F., Jordão A.M., Mendes-Faia A., 2014. Anthocyanin profile and antioxidant activity from 24 grape varieties cultivated in two Portuguese wine regions. J. Int. Sci. Vigne Vin, 48, 51-62.

Darra N.E., Tannous J., Mouncef P.B., Palge J., Yaghi J., Vorobiev E., Louka N., Maroun R.G., 2012. A comparative study on antiradical and antimicrobial properties of red grapes extracts obtained from different Vitis vinifera varieties. Food Nutr. Sci., 3, 1420-1432.

Dell'Agli M., Buscala A., Bosisio E., 2004. Vascular effects of wine polyphenols. Cardiovasc. Res., 63, 593-602.

Fadhel A., Kooli S., Farhat A., Bellghith A., 2005. Study of the solar drying of grapes by three different processes. Desalination, 185, 535-541.

Figueiredo-González M., Cancho-Grande B., Simal-Gándara J., 2013. Effects on colour and phenolic composition of sugar concentration processes in dried-on- or dried-off-vine grapes and their aged or not natural sweet wines. Trends Food Sci. Tech., 31, $36-54$.

Franco M., Peinado R.A., Medina M., Moreno J., 2004. Off-vine grape drying effect on volatile compounds and aromatic series in must from Pedro Ximénez grape variety. J. Agric. Food Chem., 52, 3905-3910

Gary W., Arianna C., 2010. Polyphenol content and health benefits of raisins. Nutr. Res., 30, 511-519.

Gatto P., Vrhovsek U., Muth J., Segala C., Romualdi C., Fontana P., Pruefer D., Stefanini M., Moser C., Mattivi F., Velasco R., 2008. Ripening and genotype control stilbene accumulation in healthy grapes. J. Agric. Food Chem., 56, 11773-11785.

Ghrairi F., Lahouar L., Amira A., Brahmi F., Ferchichi A., Achour L., Said S., 2013. Physicochemical composition of different varieties of raisins (Vitis vinifera L.) from Tunisia. Ind. Crop Prod., 43, $73-77$

Halliwell B., Gutteridge J.M.C., Aruoma O.I., 1987. The deoxyribose method: a simple 'test-tube' assay for determination of rate constants for reactions of hydroxyl radicals. Anal. Biochem., 165, 215-219.

Izcara E., González-SanJosé M.L., 2001. Análisis de los métodos rápidos de extracción para seguir la maduración fenólica de la uva. Enólogos, 3, 15-18, 28.

Jayaprakasha G.K., Singh R.P., Sakariah K.K., 2001. Antioxidant activity of grape seed (Vitis vinifera) extracts on peroxidation models in vitro. Food Chem., 73, 285-290.

Jordão A.M., Ricardo-da-Silva J.M., Laureano O., 2001. Evolution of catechins and oligomeric procyanidins during grape maturation of Castelao Francês and Touriga Francesa. Am. J. Enol. Vitic., 53, 231-234.
Karadeniz F., Durst R.W., Wrolstad R.E., 2000. Polyphenolic composition of raisins. J. Agric. Food Chem., 48, 5343-5350.

Liu F., Ooi V.E.C., Chang S.T., 1997. Free radical scavenging activities of mushroom polysaccharide extracts. Life Sci., 60, 763771 .

Mary E., Michael P., 2003. Raisin dietary fiber composition and in vitro bile acid binding. J. Agric. Food Chem., 51, 834-837.

Meng J., Fang Y., Zhang A., Chen S., Xu T., Ren Z., Han G., Liu J., Li H., Zhang Z., Wang H., 2011. Phenolic content and antioxidant capacity of Chinese raisins produced in Xinjiang Province. Food Res. Int., 44, 2830-2836.

Moreno J., Peinado J., Peinado R.A., 2007. Antioxidant activity of musts from Pedro Ximenez grapes subjected to off-vine drying process. Food Chem., 104, 224-228.

Noda Y., Anzai K., Marl A., Kohno M., Shinmei M., Packer L., 1997. Hydroxyl and superoxide anion radical scavenging activities of natural source antioxidants using the computerized JES-FR30 ESR spectrometer system. Biochem. Mol. Biol. Int., 42, 35-44.

Orak H.H., 2007. Total antioxidant activities, phenolics, anthocyanins, polyphenoloxidase activities of selected red grape cultivars and their correlations. Sci. Horticult., 111, 235-241.

Parker T., Wang X., Pazmino J., Engeseth N., 2007. Antioxidant capacity and phenolic content of grapes, sun-dried raisins, and golden raisins and their effect on ex vivo serum antioxidant capacity. J. Agric. Food Chem., 55, 8472-8477.

Pastrana-Bonilla E., Akoh C.C., Sellappan S., Krewer G., 2003. Phenolic content and antioxidant capacity of Muscadine grapes. $J$. Agric. Food Chem., 51, 5497-5503.

Re R., Pellegrini N., Proteggente A., Pannala A., Yang M., RiceEvans C., 1999. Antioxidant activity applying an improved ABTS radical cation decolorization assay. Free Radic. Biol. Med., 26, 1231-1237.

Rivero-Pérez M.D., Muñiz P., González-SanJosé M.L., 2007. Antioxidant profile of red wines evaluated by total antioxidant capacity, scavenger activity, and biomarkers of oxidative stress methodologies. J. Agric. Food Chem., 55, 5476-5483.

Rodríguez-Bernaldo de Quirós A., Lage-Yusty M.A., LópezHernández J., 2009. HPLC-analysis of polyphenolic compounds in Spanish white wines and determination of their antioxidant activity by radical scavenging assay. Food Res. Int., 42, 1018-1022.

Sanz M., Castillo M.D., Corio N., Olana A., 2001. Formation of Amadori compounds in dehydrated fruits. J. Agric. Food Chem., 49, 5228-5231.

Simonetti P., Pietta P., Testolin G., 1997. Polyphenolic content and total antioxidant potential of selected Italian wines. J. Agric. Food Chem., 45, 1152-1155.

Singleton V.L., Rossi J.A., 1965. Colorimetry of total phenolics with phosphomolybdic-phosphotungstic acid reagents. Am. J. Enol. Vitic., 16, 144-158.

Sun Y.X., Li T.B., Liu J.C., 2010. Structural characterization and hydroxyl radicals scavenging capacity of a polysaccharide from the fruiting bodies of Auricularia polytricha. Carbohydr Polym., 80, $377-380$

Vinson J.A., Zubik L., Bose P., Samman N., Proch J., 2005. Dried fruits: Excellent in vitro and in vivo antioxidants. J. Am. Coll. Nutr., 24, 44-50.

Williamson G., Carughi A., 2010. Polyphenol content and health benefits of raisins. Nutr Res., 30, 511-519.

Yilmaz Y., Toledo R., 2005. Antioxidant activity of water soluble Maillard reaction products. Food Chem., 93, 273-278.

Zhao B., Hall C.A., 2008. Composition and antioxidant activity of raisin extracts obtained from various solvents. Food Chem., 108 , 511-518 